$\underline{\text { Assiut Vet. Med. J. Vol. } 60 \text { No. } 141 \text { April } 2014}$

\title{
STUDIES ON RUMINAL DISORDERS IN SHEEP
}

\author{
A.E.A. MOHAMED \\ Department of Animal Medicine, Faculty of Veterinary Medicine, South Valley University. \\ Email: adelqena@1ycos.com
}

\section{ABSTRACT}

Received at: $27 / 2 / 2014$

Accepted: 18/3/2014
Fifty two adult native breed Egyptian sheep were suffering from ruminal indigestion. The animals were divided into three groups, based on clinical signs and ruminal $\mathrm{pH}$. The number of diseased cases with ruminal acidosis were 20, ruminal alkalosis 17 and those with ruminal tympany 15. In addition, 12 clinically adult sheep were used as control. Most cases with ruminal indigestion showed partial or complete anorexia, loss of body condition, abdominal pain, cessation of rumination and abdominal distension. Such signs differ according to the disease condition. Ruminal samples were collected from all animals and transferred to the laboratory for biophysical and biochemical analysis. All samples collected from diseased cases showed changes in the microbial activity as indicated by retardation in times of SAT, MBRT and CDT. Also, the values (m1) of GFT were increased especially in cases with ruminal tympany. All cases with ruminal dysfunction showed reduction in values and percentages of total and differential protozoal count. Biochemical analysis of ruminal fluid revealed variations in the values of sodium, potassium, chlorides and lactates among the types of indigestion.

Key words: Ruminal disorders, Sheep, Microbial activity, Ruminal fluid.

\section{INTRODUCTION}

Sheep industry constitutes a major part of animal production particularly in arid and semi-arid areas which represent more than $90 \%$ of the Egyptian land (Tawfik and Dighedy, 1980). Rumen disorders had a great clinical interest because of the high morbidity and the great losses in both production and costs of treatment of affected ruminants. From the economic point of view, fore-stomach diseases result in great losses to the producers through deaths, wasted feed, delayed marketing unthriftness of the recovered animals, incomplete utilizing of diseaseprovoking food and extra labor costs of preventive and therapeutic measures (Kimberlin, 1988).

The most common rumen dysfunction is usually defined as indigestion. The term indigestion is a general term for a group of diseases that describe mainly the reticulorminal dysfunction (Radostits et al., 2000). Indigestion in sheep is an abnormal functional disturbance of the fore-stomach. Such a disturbance may be due to over-feeding with some feed stubbles, sudden change in the diet, consumption of indigestible roughages as well as oral dosing with sulphonamides and antibiotics (Blood and Radostits, 1989).
Such a group of diseases are of the most serious and common problems that threaten the animal heath in our country. Therefore, the main objectives of this study were to:-

a- Recording the clinical findings associated with each type of ruminal indigestion in sheep.

b- Evaluation the role of physico-chemical and microscopical characteristics of ruminal contents as a guide and tool for diagnosing ruminal dysfunction.

\section{MATERIALS and METHODS}

\section{Location and date:-}

Animals of the present work were belonged to different governomental and private farms at various areas around Qena city, Qena governorate, Egypt. The work was done during the period from October 2012 to July 2013.

\section{Animals:-}

A total number of 52 adult native breed sheep 1-3 years old of both sexes were selected from field cases suffering from rumen dysfunction. The diseased 
animals were clinically examined. Animals were divided on basis of ruminal $\mathrm{pH}$ and clinical signs into three groups. The number of diseased cases with ruminal acidosis were 20, ruminal alkalosis 17 and those with ruminal tympany 15 . In addition, 12 sheep of the same ages and both sexes and clinically healthy were used as control.

About $100 \mathrm{ml}$ of ruminal juice was collected from each animal with the help of stomach tube and suction pump. The samples were transferred to the laboratory in a box containing dry ice for the immediate laboratory analysis. Each sample was divided into two parts of $50 \mathrm{ml}$. The first part was used for physical and microscopical examinations. The second part was strained using narrow sieve pores, then centrifuged at 4000 r.p.m for 15 minutes. The clear supernatent fluid was separated into clean plastic tubes and refrigerated at $-20^{\circ} \mathrm{C}$ until biochemical analysis (Dirksen and Smith, 1987).

\section{Methods:-}

All animals were clinically examined according to Kelly (1984). Physical examination of ruminal juice was conducted according to Coles (1986). Total protozoa count in ruminal fluid samples was carried out according to Hungate, (1966).

The differential count of rumen protozoa was done using the same slide of counting using high power lens (x40). Identification was carried out microscopically and depending upon the size of cell type, location of cilia, macro and micro nucleus, skeletal plates, caudal spines and projection of cuticle (Hungate, 1966 and Williams and Coleman, 1988).

\section{Biochemical analysis of ruminal fluids:- a- pH:-}

The $\mathrm{pH}$ was measured immediately after collection by using pH meter (Dirksen and Smith 1987).

\section{b- MBRT and GFT:-}

Methylene blue reduction (MBRT) and glucose fermentation (GFT) tests were done according to Coles (1986).

\section{c- Sodium (mmol/l):-}

The element was estimated using flame photometer (Model Jenway PFP7. UK). d- Potassium, Chlorides and Lactates ( $\mathrm{mmol} / \mathrm{l})$ :The elements were determined colorimetrically by using test kits supplied by GMbH Com. Germany.

\section{RESULTS}

\section{1- Clinical findings:-}

a- Ruminal acidosis (pH 4.6- 5.5):-

The severity of clinical signs varied according to the degree of $\mathrm{pH}$ value of ruminal contents. Anorexia, dullness, depression, ruminal atony $(1 / 2 \mathrm{~min})$ or complete stasis with slight tympany and congested mucous membranes were recorded in diseased cases. A splashing or tinkling sound was heard on rumen auscultation. Most of diseased sheep showed yellowish white soft faeces or even diarrhea. Grinding on teeth was a prominent clinical sign in most severely diseased cases. The body temperature, heart, and respiratory rates ranged between 37.8$39.5^{\circ} \mathrm{C}, 79-115 / \mathrm{min}$., and $39-75 / \mathrm{min}$. respectively.

\section{b- Ruminal alkalosis (pH 7.2-8.3):-}

Diseased cases showed anorexia with yellowish green soft faeces or even diarrhoea without systemic changes. Slightly doughy ruminal contents on palpation, dull sound on ruminal percussion and ruminal atony $(1 / 2 \mathrm{~min})$ on auscultation were recorded. Inappetance, emaciation and complete ruminal stasis were recorded in most diseased sheep with high ruminal $\mathrm{PH}(7.8-8.1)$.

\section{C- Ruminal bloat (tympany) pH (7.1 - 7.5):-}

The most prominant clinical signs reported in diseased cases were severe distension of the left side of abdomen at flank region with increase or complete cessation of ruminal motilities. Animals lied down and get up frequently as signs of discomfort. Tinkling or ping sound was clear on rumen auscultation in such cases especially those with severe ruminal tympany. Most of diseased cases showed rapid respiration and heart rates $(48-75 / \mathrm{min}$., and 78$115 / \mathrm{min}$ respectively). Other signs as dysponea, congestion or cyanosis of m.m were seen in some cases.

\section{2- Ruminal analysis:-}

The obtained data of the studied parameters in ruminal contents were presented in tables 1,2,3 and 4. 
Table 1:- Physical characters of ruminal juice in clinically healthy sheep and those suffering from ruminal dysfunction.

\begin{tabular}{|c|c|c|c|c|}
\hline \multirow[b]{2}{*}{ Parameters } & \multirow[b]{2}{*}{ Clinically healthy } & \multicolumn{3}{|c|}{ Types of ruminal Dysfunction } \\
\hline & & $\begin{array}{c}\text { Acid } \\
\text { Indigestion }\end{array}$ & $\begin{array}{c}\text { Alkaline } \\
\text { Indigestion }\end{array}$ & Ruminal Tympany \\
\hline Colour & $\begin{array}{c}\text {-Olive green } \\
\text {-Light to drak grey } \\
\text {-green } \\
\text { - Yellowish brown }\end{array}$ & $\begin{array}{c}\text {-Milky.grey } \\
\text {-Greyish brown }\end{array}$ & $\begin{array}{l}\text { Light to dark } \\
\text { brown }\end{array}$ & Green \\
\hline Odour & Aromatic & $\begin{array}{l}\text {-Pungent } \\
\text {-Sour }\end{array}$ & $\begin{array}{c}\text {-Putrid } \\
\text {-Ammonia } \\
\text {-Offensive }\end{array}$ & $\begin{array}{l}\text {-fermentic } \\
\text {-Aromatic }\end{array}$ \\
\hline Consistency & Slimy & $\begin{array}{c}\text {-Slimly } \\
\text {-Aqueous }\end{array}$ & $\begin{array}{c}\text {-Thin } \\
\text {-Aqueous }\end{array}$ & $\begin{array}{c}\text {-Slimy } \\
\text {-viscous }\end{array}$ \\
\hline SAT (min) & $6.7 \pm 0.26$ & $41.8 \pm 0.32^{* * *}$ & $22.15 \pm 0.11^{* *}$ & $16.4 \pm 0.75$ \\
\hline $\begin{array}{l}\text { Protozoal } \\
\text { activity }\end{array}$ & +++ & $\mathrm{O}$ or + & O or + & $\mathrm{O}$ or + \\
\hline
\end{tabular}

SAT $=$ sedimentation and floation time

Table 2:- Mean values \pm S.E of pH, MBRT, CDT and GFT in runinal fluids of clinically healthy sheep and those suffering form ruminal dysfunctions.

\begin{tabular}{ccccc}
\hline \multirow{2}{*}{ Parameters } & Clinically healthy & \multicolumn{3}{c}{ Types of ruminal Dysfunction } \\
\cline { 3 - 4 } & $\begin{array}{c}\text { Acid } \\
\text { Indigestion }\end{array}$ & $\begin{array}{c}\text { Alkaline } \\
\text { Indigestion }\end{array}$ & Ruminal Tympany \\
\hline Ph & $6.54 \pm 0.02$ & $4.8 \pm^{* *} 0.11$ & $7.4 \pm^{*} 0.31$ & $7.1 \pm^{*} 0.18$ \\
\hline $\begin{array}{c}\text { MBRT } \\
(\text { min) }\end{array}$ & $3.8 \pm 0.15$ & $8.9 \pm^{* *} 0.31$ & $7.5 \pm^{*} 0.05$ & $18.1 \pm^{* * *} 0.91$ \\
\hline CDT (hrs) & $26.4 \pm 1.2$ & $42.5 \pm^{* *} 3.2$ & $36.7 \pm^{*} 3.5$ & $39.2 \pm^{*} 4.15$ \\
\hline GFT(m) & $1.7 \pm 0.01$ & $1.9 \pm 0.04$ & $2.9 \pm^{*} 0.07$ & $3.8 \pm^{* *} 0.03$ \\
\hline
\end{tabular}

MBRT $=$ Methylene blue reduction test $\quad \mathrm{CDT}=$ cellulose digestion test

GFT $=$ Glucose Fermentation test $*=\mathrm{P}<0.05 \quad * *=\mathrm{P}<0.01 \quad * * *=\mathrm{P}<0.001$

Table 3:- Mean values \pm S.E and percentages for total and differential count of ruminal protozoa in clinically healthy sheep and those suffering from ruminal dysfunction.

\begin{tabular}{|c|c|c|c|c|c|c|c|}
\hline \multirow{2}{*}{$\begin{array}{c}\text { Condition } \\
\text { of animals } \\
\text { (NO.) }\end{array}$} & \multirow{2}{*}{$\begin{array}{c}\text { Total } \\
\text { NO./ml } \\
\text { and } \%\end{array}$} & \multicolumn{2}{|c|}{$\begin{array}{c}\text { Holotrichs spp. Abs. } \\
\text { No and } \%\end{array}$} & \multicolumn{4}{|c|}{ Oligotrichs spp. Abs. No and \% } \\
\hline & & $\begin{array}{l}\text { Isotricha } \\
\text { Spp. }\end{array}$ & $\begin{array}{c}\text { Dayst-richa } \\
\text { Spp. }\end{array}$ & $\begin{array}{c}\text { Entod-inium } \\
\text { Spp. }\end{array}$ & $\begin{array}{c}\text { Epidi-nium } \\
\text { Spp. }\end{array}$ & $\begin{array}{l}\text { Diplo-dinium } \\
\text { Spp. }\end{array}$ & $\begin{array}{l}\text { Euodip- } \\
\text { lodinium } \\
\text { Spp. }\end{array}$ \\
\hline $\begin{array}{l}\text { Clinically } \\
\text { Healthy } \\
\text { (12) }\end{array}$ & $\begin{array}{c}532341 \pm \\
86125\end{array}$ & $\begin{array}{c}25072 \pm \\
8642 \\
(4.7 \%)\end{array}$ & $\begin{array}{c}38352 \pm \\
11425 \\
(7.2 \%)\end{array}$ & $\begin{array}{c}295023 \pm \\
36721 \\
(55.4 \%)\end{array}$ & $\begin{array}{c}33139 \pm \\
9548 \\
(6.2 \%)\end{array}$ & $\begin{array}{c}71231 \pm \\
12671 \\
(12.1 \%)\end{array}$ & $\begin{array}{c}79524 \pm \\
13752 \\
(14.9 \%)\end{array}$ \\
\hline $\begin{array}{l}\text { Ruminal } \\
\text { Acidosis } \\
(\mathbf{2 0})\end{array}$ & $\begin{array}{c}70254^{* * *} \pm \\
8796 \\
(13.2 \%)\end{array}$ & $\begin{array}{c}0.0^{* * *} \\
- \\
(0.0 \%)\end{array}$ & $\begin{array}{c}0.0^{* * *} \\
- \\
(0.0 \%)\end{array}$ & $\begin{array}{c}63975^{* * *} \pm \\
12013 \\
(91.1 \%)\end{array}$ & $\begin{array}{c}3520 \pm \\
781 \\
(2.20 \%)\end{array}$ & $\begin{array}{c}1101 \pm \\
1021 \\
(4.4 \%)\end{array}$ & $\begin{array}{c}1658 \pm \\
920 \\
(2.4 \%)\end{array}$ \\
\hline $\begin{array}{l}\text { Ruminal } \\
\text { Alkalosis } \\
(17)\end{array}$ & $\begin{array}{c}198476^{*} \pm \\
29125 \\
(37.3 \%)\end{array}$ & $\begin{array}{c}4383 \pm \\
1709 \\
(3.4 \%)\end{array}$ & $\begin{array}{c}14561 \pm \\
3998 \\
(8.4 \%)\end{array}$ & $\begin{array}{c}130561 \pm \\
20109 \\
(65.8 \%)\end{array}$ & $\begin{array}{c}8723 \% \\
3257 \\
(4.6 \%)\end{array}$ & $\begin{array}{c}25721 \pm \\
8972 \\
(13.9 \%)\end{array}$ & $\begin{array}{c}4527 \pm \\
14277 \\
(3.1 \%)\end{array}$ \\
\hline $\begin{array}{l}\text { Ruminal } \\
\text { Bloat } \\
\text { (15) }\end{array}$ & $\begin{array}{c}101381^{*} \pm \\
40107 \\
(19.1 \%)\end{array}$ & $\begin{array}{c}10540^{* * *} \pm \\
2520 \\
(10.4 \%)\end{array}$ & $\begin{array}{c}13721^{* * *} \pm \\
3100 \\
(13.5 \%)\end{array}$ & $\begin{array}{c}13782^{* * *} \pm \\
4210 \\
(13.6 \%)\end{array}$ & $\begin{array}{c}20321^{* * *} \pm \\
3972 \\
(20.0 \%)\end{array}$ & $\begin{array}{c}25002^{* *} \pm \\
9011 \\
(24.7 \%)\end{array}$ & $\begin{array}{c}18015^{* * * *} \pm \\
5123 \\
(17.8 \%)\end{array}$ \\
\hline
\end{tabular}

$*=\mathrm{P}<0.05 \quad * *=\mathrm{P}<0.01 \quad * * *=\mathrm{P}<0.001$ 
Table 4:- Mean values \pm S.E for biochemical analysis of ruminal fluids in clinically healthy sheep and those suffering from ruminal dysfunctions.

Types of ruminal Dysfunction

\begin{tabular}{|c|c|c|c|c|}
\hline Parameters & Clinically healthy & $\begin{array}{c}\text { Acid } \\
\text { Indigestion }\end{array}$ & $\begin{array}{c}\text { Alkaline } \\
\text { Indigestion }\end{array}$ & Ruminal Tympany \\
\hline $\begin{array}{c}\text { Sodium } \\
(\mathrm{mmol} / \mathrm{l})\end{array}$ & $\begin{array}{c}106.12 \pm \\
3.56\end{array}$ & $\begin{array}{l}81.01 \pm^{* *} \\
2.65\end{array}$ & $\begin{array}{c}109.34 \pm \\
2.31\end{array}$ & $\begin{array}{c}75.92 \pm^{* *} \\
3.11\end{array}$ \\
\hline $\begin{array}{c}\text { Potassium } \\
(\mathrm{mmol} / \mathrm{l})\end{array}$ & $\begin{array}{c}13.07 \pm \\
0.68\end{array}$ & $\begin{array}{c}12.97 \pm \\
1.24\end{array}$ & $\begin{array}{c}13.98 \pm^{*} \\
0.01\end{array}$ & $\begin{array}{c}14.54 \pm^{*} \\
0.05\end{array}$ \\
\hline $\begin{array}{c}\text { Chlorides } \\
\text { (mmol/l) }\end{array}$ & $\begin{array}{c}22.09 \pm \\
0.72\end{array}$ & $\begin{array}{c}37.14 \pm^{* *} \\
2.05\end{array}$ & $\begin{array}{c}25.12 \pm \\
3.41\end{array}$ & $\begin{array}{c}22.89 \pm \\
2.01\end{array}$ \\
\hline $\begin{array}{l}\text { Tactates } \\
(\mathrm{mmol} / \mathrm{l})\end{array}$ & $\begin{array}{c}0.18 \pm \\
0.01\end{array}$ & $\begin{array}{c}7.85 \pm^{* *} \\
1.96\end{array}$ & $\begin{array}{c}0.07 \pm^{*} \\
0.01\end{array}$ & $\begin{array}{c}0.17 \pm \\
0.04\end{array}$ \\
\hline
\end{tabular}

$*=\mathrm{P}<0.05 \quad * *=\mathrm{P}<0.01$

\section{DISCUSSION}

\section{A- Ruminal acidosis:-}

\section{1) Clinical findings:-}

The reported clinical signs of animals suffering from ruminal acidosis were in accordance with Radostitis (2000), Braun et al. (1992) and Abdel Raouf and Omran (1986). The observed clinical signs were explained by the fact that acidosis led to depression of all centers in central nervous system on one hand, and disintegration of Gram negative ruminal flora on the other (Radosits et al., 2000). The observed diarrhoea in most cases could be attributed to the fact that lactic acid is converted to sodium lactate which passed down to the intestinal tract producing an osmotic gradient and draws water into small intestine contributing to diarrhoea (Blood and Radostitis, 1989). The increased respiratory rate with laboured respiration could be explained by stimulation of respiratory centers by lowed PH (Radostitis et al., 2000).

The amplitude and frequency of ruminal contractions were progressively diminished with eventual stasis when the rumen $\mathrm{pH}$ reached 5.0 or less. The mechanism of rumen stasis was due to the involvement of hydrogen ion receptors elsewhere in the gastro- intestinal tract and or the central inhibition of gastric center by the absorbed toxic amines and amides (Slyter, 1976).

\section{2) Ruminal Contens:-}

The recorded results (tables, 1 and 2) were agreed with those reported by Radostits et al. (2000) and Nikolov (2000). The milkey-grey colour of ruminal contents in diseased cases arrised from excessive feeding on a concentrated diet. The aqueous consistency and sour smell of rumen contents was due to excessive production of lactic acid (Radostits et al., 2000).

The times of SAT, MBRT and CDT reported in tables, 1 and 2 are used as guides to evaluate the activity of rumen microflora (Kimberling, 1998). The decreased rumen $\mathrm{pH}$ in diseased cases with rumen acidosis (tables 1,2) was due to increased lactic acid (Radostits, 2000). Microscopical examination of ruminal fluid indicated marked reduction in the activity and total count of ruminal protozoa (tables 1 and3). Highly significant decrease $(p<0.001)$ in the value of total protozoal count and percent was reached $70254 \pm 8796,13.2 \%$. also, the Isotricha and Dasytricha were completely disappeared while Entodinium spp. predominated (91.1\%) (Table 3). The total numbers and percentages of the other ruminal protozoa were greatly reduced (table 3 ). These changes were due to increased lactic acid production and hypertonicity (Radostits et al., 2000 and Nagaraja et al., 1992). Most of the ruminal protozoa are highly sensitive to increased acidity of ruminal content and cannot survive under $\mathrm{pH} 6.0$ with exception of Entodinium spp. which can survive as it is acid resistant (Hungate, 1966). Biochemical analysis of ruminal fluid revealed a highly significant increase $(p<0.01)$ in the values of both chlorides and lactates associated with significant decrease in level of ruminal sodium $(\mathrm{p}<0.01)$ No change was occurred in ruminal potassium. The obtained results are in agreement with Nikolov (2003). The marked increase in the concentration of ruminal lactate could be attributed to its excessive production in the rumen by excessive grain feeding (Radostitis et al., 2000). The decrease concentration of ruminal fluid sodium could be explained by dilution of ruminal contents by the flow of fluids to the rumen (Nikolov, 2003). The marked increase of chlorides concentration in ruminal 
fluid can be attributed to the reflus of hydrochloric acid from abomasum (Braun et al., 1992).

\section{B- Ruminal Alkalosis:-}

\section{1- Clinical findings:-}

The clinical findings of ruminal alkalosis recorded in the present work were usually varied according to the changes of rumen $\mathrm{pH}$ (Nema et al., 2003). The changes in rumen $\mathrm{pH}$ towards the alkaline side (7.4 \pm 0.31 , table 2) may be attributed to sight overfeeding on concentrated feed or feeding on low quality and quantity of concentrated diet, or suddn change of diet that impede ruminal activity (Rodestits et al., 2000).

\section{2- Ruminal contents:-}

The changes in colour, odour and consistency of ruminal contents in cases with rumen alkalosis (table 1) may be due inactivity of rumen microflora. Such phenomena are confirmed by the observed retardation time of SAT, MBRT and CDT (tables 1 and 2). The reported changes in their values with rumen alkalosis (table 2) in diseased cases is due to the increase rate of flow of saliva to the rumen which arised from continuous and prolonged feeding on rice straw with low quality of concentrated diet.

The sluggished protozoal activity and decreased count in ruminal alkalosis or acidosis could be attributed to the changes of rumen $\mathrm{pH}$ towards the alkaline or acidic side (Hungate, 1966).

Concerning the microscopical examination of ruminal fluid, it revealed a marked reduction in the activity and total number of ruminal protozoa (tables 1 and 3). Also, obvious decrease was reported among all types of ruminal protozoa (table 3 ). The lowest percentages were found among Isotricha spp. (2.20\%) and Euodiplodinium spp. (2.3\%). The reported lowering in the total and differential protozoal count may be attributed to changes in ruminal $\mathrm{pH}$.

Table (4) revealed no changes in ruminal sodium and chlorides values while potassium increased and lactates decrease in diseased cases with ruminal alkalosis. The reported elevation in ruminal potassium content may be caused by the prolonged and continous feeding animals on fibrous diet leads to more salivation which in turn increase potassium level in ruminal fluid. The marked decrease of ruminal lactates in diseased cases $($ table,4) can be resulted from excessive feeding on poor quality roughage with low quantity of concentrated diet.

\section{C- Ruminal Bloat (Tympany):- 1- Clinical findings:-}

The reported distension at the left flank of diseased cases was due to fermentation of ruminal ingesta with production and accumulation of gases in rumen.
Finally, the accumulated gases leaded to cessation of ruminal motility. The resulted ruminal tinkling or ping sound is due to ruminal atony and accumulation of gases in rumen.

\section{2- Ruminal conents:-}

The reported physical characters of ruminal contents in cases with bloat agreed with Majack et al. (1983). The reducing capacity of rumen microbiota was greatly reduced as indicated by MBRT. Increased volume of gases by GFT test indicated severe bloat in affected cases (table,2).

Microscopical examination of ruminal fluid (table 1,3 ), revealed marked reduction in the activity and total number of ruminal protozoa. Significant decrease $(\mathrm{p}<0.05)$ in total protozoal count and percent was reached $101381 \pm 40107,19.1 \%$. These results coincided with Hungate (1966), who attributed the change to the slight increase in ruminal $\mathrm{pH}$. Marked decrease in the values of all types of ruminal protozoa was recorded. The lowest percentage was reported in Isotricha spp. (10.4\%, table3). The bioehemical changes of ruminal fluid revealed higher potassium with lower values of sodium, while there is nonsignificant change in ruminal chlorides and lactates (table 4). In mild cases of ruminal tympany, the amount of saliva increased to the degree which could interfere with buffer capacity of rumen fluid and may act to elevate the $\mathrm{pH}$ and potassium contents in rumen, (Radostits et al., 2000).

\section{CONCLUSION}

It could be concluded without doubt that, improper feeding, gazing or feeding on field stubbles or bad quality roughages and feeding on decayed or putrified materials as garbage are among the important factors causing ruminal disorders in sheep.

With ruminal dysfunction most of body organs or systems will suffer from illness.

As the microfuna is important for ruminal digestion, thus keeping them alive and active is very essential.

The description of biophysical and biochemical integrities of ruminal juice are used as a guide for proper diagnosis of ruminal disorders.

\section{REFERENCES}

Abdel Raouf, M.M. and Omran, H. (1986): Clinical, biochemical and histopathological studies on rumen acidosis in sheep. Alex. J. Vet. Sci., Vol.3 N o.1:535-534.

Blood, D.C. and Radostits, O.M. (1989): Veterinary Medicine. $7^{\text {th }}$ ed., Bailliere, Tindall, London, U.K. 
Braun, U.; Araibs, T. and Schefer, U. (1992): Rumnal lactic acidosis in sheep and goat. Vet. Rec. vol. 130:342-349.

Coles, E.H. (1986): Veterinary Clinical Pathology. $4^{\text {th }}$ ed., W.B. Saunders company, Philadelphia, U.S.A.

Dirksen, V.G. and Smith, M.C. (1987): Acquisition and analysis of bovine rumen fluid. Bovine Practitioner, No.2:108-116.

Hungate, E. (1966): Rumen and its Microbes. $1^{\text {st }}$ ed., Academic press, New York, U.S.A.

Kelly, W.R. (1984): Veterinary Clinical Diagnosis. $3^{\text {rd }}$ ed., London, Balliere, Tindall.

Kimberling, C.V. (1988): Jensen and Swiff's disease of sheep. $3^{\text {rd }}$ ed., Lea and febiger. Philadelphia, U.S.A.

Majack, W.; Howarth, R.E.; Cheng, K.J. and Hall, J.W. (1983): Rumen condition that predispose to pasture bloat. J. Dairy Sci., Vol. 66: 1683-1688.

Nagaraja, T.G.; Towne, G. and Beharka, A.A. (1992): Metabolism of ruminal fermentation by ciliated protozoa in cattle, fed a high grain diet. Appl. and Envir. Micro. Vol.58, No.8: 2410-2414.

Nema, R.K.; Tiwari, S.K.; Rov, S.; Galdhar, C.P. and Bhandekar, S.K. (2003): Studies on the simple indigestion in goats and its treatment with Appevet. Indian Vet. J. Vol.80, 564-566.

Nikolov, Y. (2000): Some biochemical changes in cerebrospinal fluid, blood and ruminal fluid in experimental rumen acidosis in buffalo calves. Indian Vet. J. Vol. 77: 957-960.

Nikolov, Y. (2003): Biochemical alterations in rumen liquor, blood, cerebrospinal fluid and urine in experimental acute rumen lactic acidosis in sheep. Indian Vet. J. Vol.80: 36-39.

Radostits, O.M.; Blood, C.D. and Gay, C.C.(2000): Veterinary Medicine. $9^{\text {th }}$ ed., Bailliere, Tindall, London.

Radostits, O.M.; Mayhew, I.G. and Hausten, D.M. (2000 a): Veterinary Clinical Examination and Diagnosis. London, philadelphin, U.S.A.

Roussel, A.J. (1990): Rumen analysis as a diagnostic tool. Proceeding SAVMA Symposium. Texas $A$ and $M$ 1126-113, UNIV. Texas, U.S.A.

Slyter, I.I. (1976): Influence of acidosis on rumen function. J. Anim. Sei. Vol. 43.No.4:910-929.

Tawfik, M.A. and Dighedy, N.S. (1980): Studies on gastro-intestinal nematodes of Egyptian sheep. J. Vet. Med. Ass. Vol.40, No.4: 83-87.

Williams, L. and Coleman (1988): The rumen protozoa in Hobson edition, Rumen microbial Ecosystem. 77-128, Elsevier Applied Sciences, U.S.A.

\title{
دراسات عن إضطر ابات الكرشى فى الاغنام
}

\author{
عادل السبا محمد \\ Email: adelqena@lycos.com
}

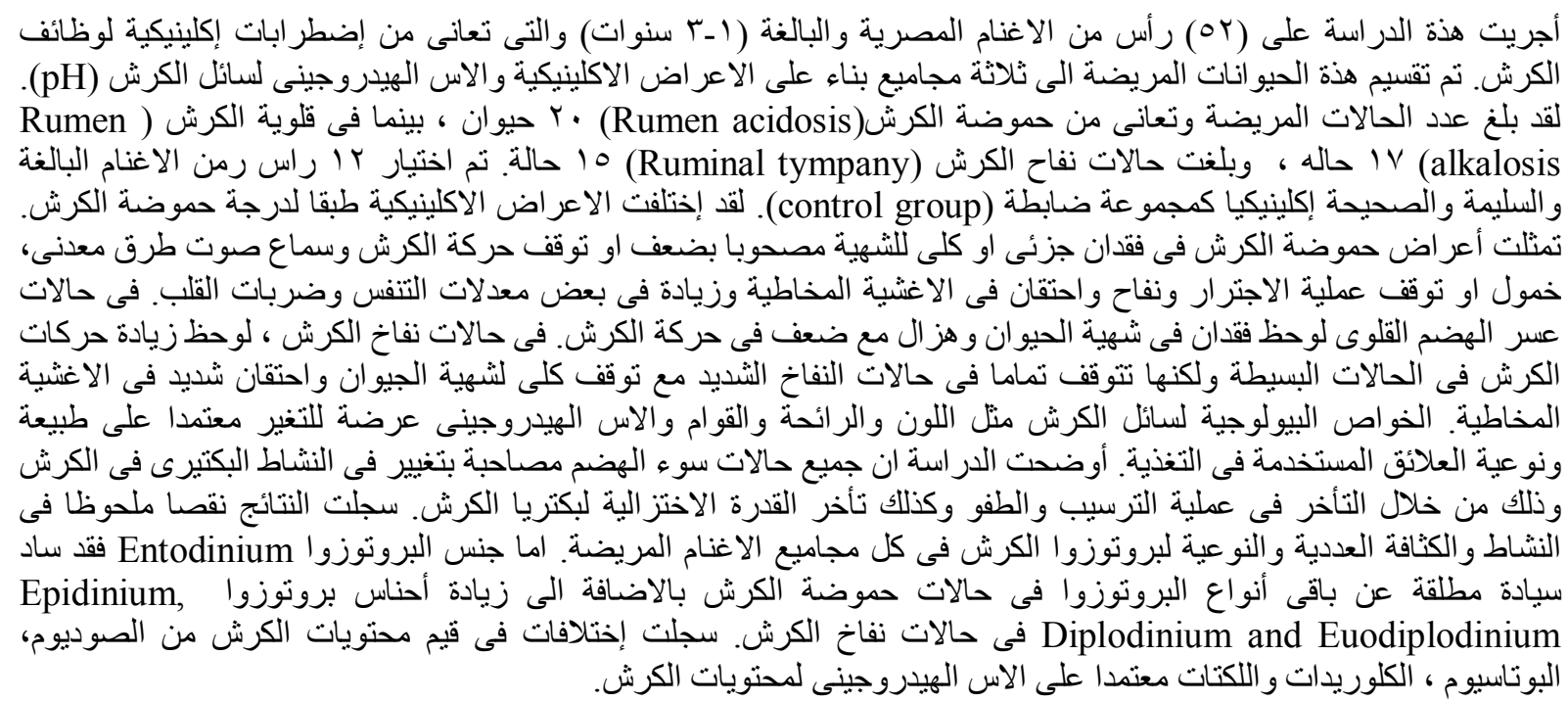

